\title{
USPOSOBLJENOST ZA DELO V IZOBRAŽEVANJU ODRASLIH IN RAZVOJ KARIERE
}

\section{POVZETEK}

Ker vemo, da so se razmere v družbi spremenile, zagotovo vemo tudi, da se bodo posledično spremenile tudi zahteve glede profesionalnih vešcin predvsem tisth profesij, ki so tesneje odvisne od družbenih razmer. Poklic učitelja je v tem kontekstu gotovo eden od najbolj občutjjivih. Kot opažamo, vse več učiteljev otrok in mladine začenja videti kot del svojega profesionalnega dela tudi izobraževanje odrastih. Vprašanje je, ali je to bolj dodatek, honorarno delo in priložnost za premoščnje

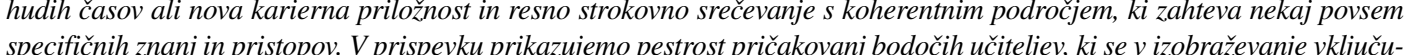
jejo z zelo različcnih strokovnih področij.

Kliučne besede: izobraževanje, izobraževanje odraslih, učitelji, poklicni in profesionalni razvoj, razvoj kariere

\section{A CAREER IN ADULT EDUCATION - ABSTRACT}

It is a well-known fact that the societal conditions have changed. We also know that as a consequence the demands for professional skills will change, especially of those professions which depend to a large extent on societal circumstances. In this context the profession of a teacher is among the most sensitive ones. We notice that more and more teachers of children and youth are begining to view adult education as a form of their professional work. However, the question remains if this is more something added, a source of additional income and the opportu-
nity to overcome turbulent times or we can speak about a new career opportunity and a serious professional encounter with the coherent field which demands new specific knowledge and approaches. In this article we present the versatility of expectations of teachers to be, who get included in education from vary different professional fields. Key words: education, adult education, teachers, vocational and professional development, the development of a career

Ena temeljnih učiteljevih nalog je skrb za nenehno poglabljanje kakovosti dela. Učitelja $\mathrm{v}$ tem smislu lahko pojmujemo kot ključnega akterja novih družbenih tokov in pobudnika skupnosti, učiteljs sodelovanja drugimi udeleženci izobraževanja in na ravni sodelovanja med generacijami. Tu je usodnega pomena učiteljeva zmožnost za razvoj in raziskovanje svojega lastnega dela kot tudi za načrtovanje in razvoj svoje individualne kariere $\mathrm{v}$ kontekstu organizacije ali skupine, $\mathrm{v}$ kateri dela Z Z drugimi besedami: pomembno je - ne le za učitelja, za družbo nasploh, kako bodo učitelli razvijali ne le svojo poklicno, resion temveć tudi profesionalno identiteto, skrbeli za svoj karierni razvoj in kakšen pomen temu daje tudi njihovo strokovno okolje. $\mathrm{V}$ tem kontekstu je vprašanje o kakovosti njihovega izobraževanja in usposabljanja pomembno ne le z vidika posameznika, ampak tudi z vidika kakovostnega razvoja celotne družbe.

\section{ZOBRAŽEVANIE IMA} DOLGOROČEN VPUIV NA VKLJUČENOST V DRUŽBO

Opozorila najnovejših evropskih primerjalnih analiz (npr. raziskava In-cluded, ${ }^{2}$ ki je v teku) ponovno potrjujejo precej neprijetno povezavo med izključ izja: nižja stopnja izobrazbe za posameznika pomeni bistveno večje tveganje, da se uvrsti med ranljive skupine prebivalstva; obstaja očitna povezava med izključenostjo iz izobraževanja in brezposelnostjo; analiza na evropski ravni nakazuje, da ljudje z nižjo stopnjo izobrazbe politiko oziroma aktivno participacijo $\mathrm{v}$ družbi dojemajo ko manj pomemben vidik življenja (le približno pet odstotkov tistih Evropejcev, ki imajo samo osnovnošolsko stopnjo izobrazbe, jo ocenjuje kot pomembno); treba se je soočiti s skrbjo, da zaostrene gospodarske razmere lahko resno zaosijo odnos vecinskih supin do drugačnih, manjšin in predvsem ranljivih skupin prebivalstva (kar se že kaže v nekaterih delih Evrope) (Vrečer in Javrh, 2009).

Pomanjkljiva razvitost temeljnih zmožnosti določenim skupinam prebivalstva onemogoča izrabo priložnosti za uporabo teh sistemov, ki naj bi bili v načelu demokratično urejeni (Ivančič in drugi, 2008; Možina in drugi, 2009). Revščina močno omejuje možnosti pridobiti določeno stopnjo izobrazbe, stopnja izobrazbe pa sodoloča zmožnosti oziroma kompetence predvsem pri pripadnikih ranljivih skupin, saj imajo praviloma ključne zmožnosti bistveno manj razvite. Za to revščina ni omejena le na revne države Unije, pojavlja se v vseh okoljih Evrope in se skriva za navideznim izobiljem. Izobrazbeni dosežki posameznikov jasno korelirajo z vključenostjo oziroma izključenostjo na različnih področjih družbe. Vpliv se kaže denimo v zmožnostih uveljavljanja posameznikovih pravic na področjih zaposlovanja zdravja, stanovanjskem področju in drugih (Vrečer in Javrh, 2009).

Posledično je mogoče videti poglabljanje neenakosti, ki se posredno dogaja celo na samem področju izobraževanja. Tako na nacionaln kot na evropski ravni se pri ponovnem vključevanju t. i. ranljivih skupin prebivalstva $v$ izobraževanje nakazuje težko prepoznaven in precej zapleten dejavnik. Gre za strokovno (in osebno) zelo angažirano delovanje izobraževalcev/učiteljev, ki ranljivim vlivajo upanje v spremembo s pomočjo izobraževanja. Po prvih uspehih pa se največkrat pokažejo neprema- gljive ovire. Te izhajajo iz različnih okoliščin $\mathrm{v}$ katere so ranljive skupine najpogosteje vpete (zasvojenosti, osebnostne težave, družins problemi, revščina ...), temu sledi grenko razočaranje posameznikov, ki so začeli upat v spremembo. Prav to je najbolj neugodna posledica. Zdi se, da je lahko tudi to razočaranje dolgoročen dejavnik izkljucevanja iz kakršnekoli oblike izobraževanja (Javrh, 2009).

Posameznik, ki bo integriran in bo kot tak sposoben vstopati v družbeno dogajanje, je noslec zadostne kakovosti v odnosu do drugačnih in morda tudi manj zaželenih. Prav učitelji imajo glede teh prizadevanj družbe povsem posebno mesto. Ko namreč natančneje pogledamo pomen in vpliv učitelja kot vzornika oziroma modela zaželenega družbenega angažiranja, postaja vse bolj jasno, da mora učitelj najprej osebno doživeti in sprejeti idejo o enakosti možnosti, šele nato jo bo lahko zares učinkovito posredoval učečim.

\section{NOVE DRUŽBENE OKOLIŠČINE} SPREMINIAJO PROFESIONALNI RAZVOI

Gospodarstveniki vedno glasneje opozarjajo na nevarnosti razhajanja $v$ izobraženost in usposobljenosti kadrov ter znanjih, ki ustrezajo trenutnim potrebam delodajalcev in obstoječi ponudbi delovnih mest. Znanje, usposobljenost in kompetence so $\mathrm{v}$ družbi znanja postali opredeljeni pogoj konkurenčnosti globalnega trga dela. Prav to pa je $\mathrm{v}$ kriznih časih in posebno še $\mathrm{v}$ tem trenutku zelo pomemben dejavnik za obstoj. Z drugimi besedami: za družbo znanja, ki je deklarirani cilj integrirane Evrope, je okviru kreiranja ustreznih politik velikega pomena identificiranje sedanjih in prihodnjih potreb po usposobljenosti ter sodobnih znanji ne le nupoabrikovu, tenveč tudi tish, $\mathrm{ki}$ le »uporabnikov «, temvec te uporabnike temeljni spretnosti naučijo, torej učiteljev. Pomemb- 
no je razmisliti tudi o položaju učiteljskeg poklica $\mathrm{z}$ vidika trga delovne sile, tako položaju samega poklica do drugih poklicev kot tudi širše, saj učitelji za trg dela izobražujejo bodočo delovno silo. Kritično in sistematično spremljanje in identificiranje novih potreb omogoča ustrezno odzivanje, stem pa tudi višjo stopnjo socialne vključenosti.

Novi družbeni tokovi in pobude, ki se ta trenutek razcvetajo v združeni Evropi - kot so na primer ekonomska in kulturna globalizacija, trajnostni razvoj, globalno izobraževanje in učenje, socialna pravičnost, novi vidiki medgeneracijskega sodelovanja in soočanje s posledicami trka med generacijami oziroma potrebo po razrešitvi medgeneracijskega konflikta itd. - nujno vplivajo (in bodo vplivali) na profesionalni razvoj evropskih učiteljev. Nepredvidljiva tržna ekonomija ne more dovolj kmalu napovedati vseh potreb, čeprav lahko na podlagi sektorskih premikov in različnih scenarijev sklepa na možno povečanje oziroma zmanjševanje potreb po posameznih znanjih in usposobljenostih (Vrečer, 2010). Vse bolj je jasno, da bi za ta namen potrebovali odlične, vrhunsko opremljene izobraževalce, ki bodo znali razumeti »znamenja časov«, ki se bodo nenehno učili tudi sami in ki bodo ohranjali kritično distanci do številnih oblik globalizacijskih procesov ter bodo znali precizno ločevati med tistimi interesi, ki pretežno iz-

hajajo iz vulgarno-kapitalističnih motivov, in tistimi, ki so v jedru vselej zavezani humanističnemu naboju izobraževanja. Nehote se v ospredje pomikajo vprašanja poslanstva in odgovornosti konkretnih učiteljev, ki so vpeti v vzgojno-izobraževalne procese ne glede na stopnjo izobraževanja. Kot so po(Ez) 1996; Kle 2000 in (Er), jeck Wragg, 1996, Klerte, 2000 in drugi), je ključni dejavnik pri uvajanju novosti in nujnih sprememb izobraževalni sistem na izvedbeni ravni vedno učitelj. Učitelji so torej usodni člen. Ni vseeno, ali bodo podlegli pritiskom trenutnih družbenih procesov ali pa bodo s svojo držo in vzgledom braniki in zagovorniki temeljnih redned ne grede a poitçne in gospoly pritiske. $Z$ vidika pritusk. Z vidika izobraževanja odraslih je prav ta vloga učitelja izredno pomembna.

Ključno nadaljnje vprašanje je, kje in kdaj naj učitelji dobijo vpogled $v$ navedene trende, nova aktualna spoznanja, jih kritično presodijo in na podlagi presoj oblikujejo svoja trdna stališča. Nova vedenja (in izkusva) ju (izvedbenih kurikulov, ki jih bodo utrjevali v njihovi strokovni avtonomiji, na drugi strani pa dali zmožnosti, da bodo lahko sledili osebnemu poslanstvu. Analiza dela angažiranih in kritičnih učiteljev pri nas je nakazala (prim. Javrh, 2009; Jamšek in Javrh, 2009), da je za to potrebnih več pogojev. Edent je ustezno izobaževaje in usposabjimi uč ustrezno izobraževanje in usposabljanje
uciteljev.

Ustrezna poklicna socializacija, ki vključuje različne dimenzije odgovorov na aktualne spremembe v družbi in pri delu, je tista, ki lahko učitelja na celotni poklicni poti pripravlja, potrjuje in usmerja v ustrezno smer kariernega razvoja. Ob tem pa se je seveda treba zavedati, da gre za dalj časa trajajoč proces, ki mora biti ustrezno podkrepljen, usmerjan in kdaj pa kdaj tudi korigiran. Tako s strani posameznika kot tudi s strani ustanove. Na proces poklicne socializacije in posledično oblikovanje identitete učiteljev je mogoče vplivati predvsem $z$ ustreznim izobraževanjem in usposabljanjem tako na in usposabljanjem izpopolnjevanja (prim. Valenčič Zuljan in drugi, 2007). Slednje ima omejeno, vendar nikakor ne zanemarljivo vlogo.
Postaviti pa je treba še naslednje vprašanje: ali so učitelji imeli ustrezne sistemske pogoje za pridobitev zmožnosti, potrebnih za doseganje vseh opisanih zahtev, in ne nazadnje koliko priložnosti imajo ta trenutek za nenehen vzdržno naravnan profesionalni razvoj. Predvsem tisti učitelji, ki so nove zmožnosti pridobili in jih razvili do te mere, da so prišli do novih pogledov na spremenjene družbene okoliščine in so zmožni novih načinov ravnanj, bodo zahtevam kos. Študije (prim. Zelena knjiga o izobraževanju učiteljev v Evropi, 2001; Marentič Požarnik in drugi, 2005; Javrh, 2006; Javrh, 2008 itd.) kažejo, da je med temeljnimi dejavniki, ki pomembno vplivajo na ravnanja in prepričanja učitelja, tudi način, kako poteka oblikovanje poklicne identitete oziroma kako poteka njegova poklicna socializacija. Ugotovitve raziskav kažejo, da poteka poklicne socializacije ne moremo omejiti le na obdobje priprave na poklic in prvih nekaj let dela.

\section{UČITELJEV ODNOS DO}

Učiteljeva stališča do kariernih vprašan imajo z njegovo edinstveno vlogo iniciatorja in spodbujevalca vzdržnega razvoja veliko širše in dolgoročnejše posledice, kot se zdi na prvi pogled. Prav učitelj je že mladim generacijam pomemben pozitiven ali negativen vzonik v dobi nijhove predkaiere. Odraslim Odraslim udeležencem izobraževanj je ko njihov vrstnik do določene mere referenč na točka, primer dobre prakse, dokaz, da je kakovosten karierni razvoj mogoč. Ta vpliv učitelj v vlogi izobraževalca odraslih lahko ima le, če prej ustrezno načrtuje, ovrednoti in vodi svojo lastno karierno pot ter svoj poklicni in tudi profesionalni razvoj. ${ }^{3} \mathrm{~V}$ nasprotnem primeru postaja antivzornik, poosebljenje napak in spodbujevalec negativnega, zavračujočega odnosa odraslih do izobraževanja in usposabljanja.
Seveda učiteljeva naloga $\mathrm{ni}$ preprosta. Kot posameznik, najprej odgovoren za lastno poklicno pot, se mora učitel vnaprej opredeliti do vprašanj, kako organizirati osebna razmerja med delom, domom in osebnim razvojem, da bodo pripomogla $\mathrm{k}$ pozitivnim procesom njegovega karierneg razvoja. Le tako navidezne možnosti, ki se skozi komercialni pristop različnih ponudnikov in interesentov tudi učiteljem vse bolj ponujajo $\mathrm{v}$ idealiziran obliki, tako njih samih kot mladine in odraslih ne bodo zavajale na stranske poti in dodatno oteževale razvoja.

Sodobni učitelj mora imeti vrsto kompetenc, ki jih v preteklosti ta poklic ni poznal. Večje novosti so predvsem globalna razsežnost, vloga posameznika kot državljana EU, pozitiven odnos do kulturne in narodnostne pestrosti, mosilnost, etična dža do družbe informacij in uporabe znanja, obvladovanje najsodobnejše izobraževalne komunikacijske tehnologije in poznavanje ter zmožnos uporabe številnih novih omrežij informacij. Sodobni učitelj mora poleg učiteljskih kompetenc izražati pozitiven odnos do kulturne, narodnostne in seksualne pestrosti, mobilnosti, IKT ipd.

Nabor teh novih kompetenc, ki naj bi ji učitelj razvil v temeljne zmožnosti, zahtev od učitelja in od izobraževalnega sistema, ki učitelje pripravlja ter usposablja za delo, precejšnje premike. Ti premiki so potrebni ne le v vsebinah, ampak tudi v spretnostih, ravnanjih in drž, ki jo učitelj vzpostavlja do dela in okolja. To je lahko breme, hkrati pa nova možnost, izziv, da poklic ućtela postop začne dobival bolj ugle ncitelja postopno trenutno pripada. 


\section{IZOBRAŽEVALCI ODRASLIH}

Izobraževalci odraslih imajo lahko zelo razupoštevanju njihovega zaposlitvenega statusa) vpliva na njihove možnosti za delo, usposobljenost in motivacijo za izobraževanje te iskati področje razvoja kariere izobraževalc odraslih in odgovoriti na vrsto vprašanj. Za izobraževalce odraslih je na splošno znapodročja dela z mladino in otroki. Po podatkih Statističnega urada RS o izobraževalcih braževanja kažejo, da večina učiteljev, ki poučujejo v osnovnih šolah za odrasle, poučuje tudi v osnovnih šolah za mladino. Statistični podatki o strokovnih delavcih, ki delajo pri lične vloge in naloge, ta pestrost pa (tudi ob seveda na kariero. Avtorice poročil Prik osežkov in razvjhih izzivov (2008) med drugim ugotavljajo, da bi veljalo sistematično razčilno, da se razmerje med redno zaposlenimi in honorarnimi sodelavci nagiba na stran honorarnih sodelavcev, ki večinoma prihajajo $s$ odraslih v programih osnovnošolskega izoizvajalcih nodajnjega izobraževanja, kažejo, šcvilo učiteljev, izobraževanja otrok in mladine, narašča, šte-

vilo drugih strokovnih delavcev $\mathrm{v}$ izobraževanju odraslih pa upada (v: Prikaz dosežkov in razvojnih izzivov, 2008)

\section{KLJUČEVANJE}

\section{STROKOVNIAKOV RAZLIČNIH}

\section{STROK V IZOBRAŽEVANJE}

Prikazali bomo nekaj rezultatov raziskave o stanju v programu usposabljanja za bodoče učitelje, ki prihajajo iz drugih, nepedagoških strok $^{4}$ in bi radi postali učitelji v najširšem pomenu besede, tako učitelji otrok in mladine kot izobraževalci odraslih. Postavlja se namreč vprašanje, $v$ kolikšni meri dodiplomsko izobraževanje omogoča in podpira formiranje ictorn bodočih učiteljev, učitejev, ki bodo svojo kariero razvijali in s tem prispevali dinamiko $\mathrm{v}$ razvoju poklica kot takega. Gre za program pedagoško-andragoškega izobraževanja (PAI), ki ga izvajajo vse tri slovenske univerze (v Ljubljani, Mariboru in Kopru). Vanj se lahko vključijo odrasli z ki ga

Izobraževalci izobraževalcev že opozarjajo na nove potrebe po znanjih o razvoju kariere učiteljev, ki delajo v izobraževanju odraslih. Analiza fokusnih skupin z naslovom Razvoj novih pristopov pri izpopolnjevanju andragoških delavcev (Žalec, Đorđevič, 2009) je recimo pokazala, da bodo med nujnimi kompetencami izobraževalca odraslih v prihodnosti tudi take, ki zahtevajo dobro poznavanje splošnih zakonitosti o razvoju poklicne poti, njenega načrtovanja in spreminjanja. Kot ugotavljata Žalec in Đorđevič, ponudba na tem področju ni zadostna niti celovita, saj v Sloveniji nihče sistematično ne razvija svetovalne dejavnosti za karierno rast izobraževalcev odraslih. Premalo je programov splošnega andragoškega izpopolnjevanja, ki bi različnim strokovnjakom v procesu razvoja na tem področju izbrane profesionalne poti omogočili, da si pridobijo ustrezno znanje in kompetence. To sta avtorici ponazorili z naslednjo izjavo enega od udeležencev: »Kar je pomembno, pa je razvoj sistematičnega izobraževanja andragogov, nekega temeljnega modela, ki bi se nadgrajeval. V mislim imam izobraževanje, ustrezno za nekoga, ki bi se na novo zaposlil v izobraževanju odraslih in bi si lahko tako pridobil temeljna znanja, ta pa bi kasneje nadgrajeval «(Prav tam: 42.) Brez predhodnega dobega

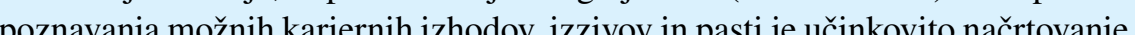
poznavanja možnih kariernih izhodov, izzivov in pasti je učinkovito načrtovanje in razvoj oseb-
ne kariere težko pričakovati. poučevanje v pedagoških in andragoških pro- gramih. Naš vzorec udeležencev PAI je bil priložnosten. $Z$ anketnim vprašalnikom smo anketirali udeležence programa za pridobitev pedagoško-andragoške izobrazbe na ljubljanski univerzi. V vzorec je bilo v šolskem letu 2008/2009 v prvi meritvi vključenih 119 oseb, v drugi pa 97. Sestavljale so ga tri različn li program sk kov vzorca); skupina udeležencev bez dosedanjih pedagoških izkušenj, ki so obiskoval program na Filozofski fakulteti (28 odstotkov vzorca); in skupina udeležencev programa na Filozofski fakulteti, ki že imajo pedagoške izkušnje, a formalno nimajo ustrezne pedagoško-andragoške izobrazbe (27 odstotkov vzorca).

Daleč največ udeležencev ankete je $\mathrm{v}$ odprtem odgovoru izražalo pričakovanje, da bodo s programom za pridobitev pedagoško-andragoške izobrazbe (PAI) poleg formalnega potrdila o usposobljenosti za poučevanje pridobili »znanje za delo v praksi « in »ustrezne kompetence«. Precejšen delež jih je omenjalo željo po teoretičnih znanjih iz pedagogike, psihologije, andragogike, potrebo po razumevanju stroke, ne pa izkušenj. Nekateri so se nadejal bolj temeljnih vsebin, kot so: »spoznati, kaj je dober pedagog «, »kaj je poučevanje in kaj je vzgoja «, »kakšne so prave vrednote«, »občutek za ravnanje z ljudmi, poudarjena socialna nota $«$, , poudar empatija «, »vpogled v področje«.

Drugi so se osredotočali na nekatera bolj specifična strokovna znanja, denimo sposobnost predstavitve in prenašanja znanja, znanje za delo $\mathrm{z}$ otroki in odraslimi, vpogled $\mathrm{v}$ delo uči telja, občutek, kaj je pravi pristop do učencev, pomoč pri organizaciji izobraževanja, ali pa jih je zanimala seznanitev $\mathrm{z}$ metodami izobraževanja, kako razviti dobro klimo med poslušalci in predavateljem. Menili so tudi, da bodo pridobili več znanja za mentorsko delo z dijaki skupine: skupina udeležencev, ki so obiskova- in študenti (npr: »biti boljši predavatelj $\ll$ )

Udeležba $\mathrm{v}$ usposabljanju jim je odprla nov pogled na znane probleme, radi pa bi slišal praktične izkušnje preostalih udeležencev. Nekateri so pričakovali, da bodo pridobili več zmožnosti za javno nastopanje in več samozavesti. Za nekatere je usposabljanje razširitev obzorja, pridobivanje dodatnega znanja, razširitev že obstoječil znanj ali splošna izobrazba: »celovita izobrazba s tega področja, ki mi bo koristila tako poklicnem življenju kot v življenju nasploh«.

Le nekateri so izražali pričakovanja, da bodo z udeležbo vzpostavili pomembne stike kolegi in nova poznanstva. Med udeleženci so bili tudi taki, ki so bili bolj osredotočeni na znanje za lastne potrebe in življenje ter so pričakovali predvsem veliko izmenjave lastnih prepričanj in oblikovanja pristopov, razrešitev dvomov, kaj je prav in kaj ne«, »seznam koristne literature «. Med njimi pa so tudi taki, ki pridobivanje pedagoško-andragoške kvalifikacije vidijo kot novo karierno možnost za tretje življenjsko obdobje, in sice kot: »možnost poučevanja na ljudski univerzi, ko bom v pokoju《, «morda bom b med odmori in predavanji«.
Udeleženci izobrazelijo pridobiti raksi in 
SLIKA: Vsebina pričakovanj bodočih učiteljev iz drugih panog

PREVLADUJOČE PRIČAKOVANJE strokin.......

zmožnost za zaposlitev, kompetenc

znanje za prakso

teoretična znanja

znanje za delo $\mathrm{z}$ otroki in odraslimi

pristop do učencev

razrešitev dvomov, kaj je prav in kaj ne

vpogled $v$ delo učitelia

\section{vpogled v področje}

dodatna znanja, razširitev že obstoječih

občutek, kaj je poučevanje in kaj je vzgoja

splošna izobrazba

spoznavanje lastnih prepričanj in oblikovaje pristopov

pomoč pri organizaciiji izobraževanja

seznanitev z metodami izobraževania

sposobnost prezentiranja in prenašanja znanja, javno nastopanje

razširitev obzorja

stiki s kolegi, nova poznanstva

znanje za lastne potrebe in živlienje

veliko izmenjave $m$

drugo:

seznam koristne literature

razumevanje stroke, ne pa izkušen

razviti dobro klimo med poslušalci in predavateljem

več znanja za mentorsko delo $z$ dijaki, študenti (biti boljši predavateli

možnost poučevanja, ko bo $v$ pokoju

morda bom bliže želenim cilien

kakšne so prave vrednote pri tem delu

občutek za ravnanje z ljudmi (socialna nota)

več samozavesti

nov pogled na znane probleme

poudarek, da je za učitelja pomembna empatija

poznati, kaj je dober pedagog

spomin na zabavna druženja med odmori in predavanji

celovita izobrazba s tega področja, koristna tako v poklicnem kot v zasebnem živlienju

večja fleksibilnost

povezanost teose

REDKEJE IZRAŽENO PRIČAKOVANJE

Udeležence smo natančneje spraševali tudi, kakšno spremembo v karieri jim bo to usposabljanje omogočilo. Skupaj slaba polovica udeležencev računa s tem, da bodo postali učitelj (43,5 odstotka). 10,2 odstotka jih ne pričakuje nobene spremembe. Zanimiva pa je razlika pričakovanjih med začetno in končno meritvijo.

PREGLEDNICA 1: Pričakovanie karierne

(a)

\begin{tabular}{|l|l|l|l|l|}
\hline $\begin{array}{l}\text { Pričakovana } \\
\text { karierna } \\
\text { sprememba }\end{array}$ & \multicolumn{2}{|l|}{$\begin{array}{l}\text { Meritev } \\
\text { ob začetku }\end{array}$} & \multicolumn{2}{l|}{$\begin{array}{l}\text { Meritev } \\
\text { ob koncu }\end{array}$} \\
\hline & F & $\%$ & f & $\%$ \\
\hline $\begin{array}{l}\text { Postal } \\
\text { bom učitelj }\end{array}$ & 54 & 45,4 & 40 & 41,2 \\
\hline $\begin{array}{l}\text { Ne bo spre- } \\
\text { membe }\end{array}$ & 9 & 7,6 & 13 & 13,4 \\
\hline Drugo & 53 & 44,5 & 44 & 45,4 \\
\hline Skupaj & 116 & 97,5 & 97 & 100,0 \\
\hline Ni podatka & 3 & 2,5 & $/$ & $/$ \\
\hline Skupaj & 119 & 100,0 & 97 & 100,0 \\
\hline
\end{tabular}

Kar 13 udeleženih ob izteku usposabljanja ne pričakuje več, da bodo postali učitelji, čeprav so to pričakovali ob vstopu v usposabljanje, vsaj štirje pa menijo, da spremembe ne bo, čeprav so si jo sprva obetali. Zelo zanimivi pa so podatki pod izbiro Drugo, saj je kar 45 odstotkov anketirancev izbralo to možnost in v odprtem odgovoru tudi pojasnilo, kaj pričakujejo. Najbolj je zanimiva
PREGLEDNICA 2: Kakšno spremembo v karieri bo omogočlla pridobitev pedagoško-a
izkušniam

\section{MERITEV OB ZAČETKU \\ MERITEV OB KONC}

- pomagalo mi bo pri iskanju zaposlitve

- bom predavatelj

- postal bom pedagog v CUDV

- širši spekter možnih zaposlitev

- bolj izobražen, praktično delo

- začetek/znanje osnov poučeva-

nja in podajanja snovi

pridobitev teoretičnega

pedagoškega znanja

- večja možnost zaposlitve

v vzgojno-izobraževalnih

enotah, na področju šolstva in

izobraževanja, več možnosti

za zaposlitev na šoli

- morda kdaj postanem

predavatelj

ali organizator predavanj

- mentor študentom

- vodja pripravnikov

- možnost pedagoškega dela v

javnem glasbenem zavodu

- bolj bom samozavesten in

ciljno usmerjen pri pripravi

izobraževanj za zaposlene $\mathrm{v}$

organizaciji, kjer sem zaposlen

- delo na šoli kot svetovalni

delavec

- rada bi bila učiteljica

- možnost se zaposliti na šoli kot socialni delavec

priznani izpiti mi bodo dali

nekaj novih možnosti za

delo in nadaljnjo izobrazbo

suverenost na delovnem me-

stu/kakovostno svetovanje

staršem

- delo z odraslimi na LU

- zelo rad bi postal učitelj

- možnost, da postanem

učiteljica

- Širše možnosti v okviru

pedagoškega dela, boljša

usposobljenost

skupina udeležencev, ki so imeli le malo al nič pedagoških izkušenj. Razlika v njihovih pričakovanjih ob začetku in koncu usposabljanja kaže, da ob koncu usposab bodoči učitelji bodoci uciteji pičakujejo predvsem več suverenosti, torej poklicne utrditve, medtem ko so bili na začetku veliko bolj usmerje ni v razmišljanje o napredovanju oziroma možnih kariernih premikih. 
Primerjava med začetno in končno meritvio v skupini udeležencev, ki so večinoma že imeli pedagoške izkušnje oziroma so že učili, pokaže nekoliko drugačno težnjo.

Udeleženci v tej skupini želijo najprej zadostiti formalnim pogojem, saj se bodo lahko poklicu učitelja docela predali. Odločeni so, da svojo kariero razvijajo na tem področju.

\section{PREGLEDNICA 3: Kakšno spremembo $v$ karieri bo omogocila pridobitev pedagoško-andragoške usposobljenosti skupini $\mathbf{z}$ več pedagoškimi izkušnjam}

\begin{tabular}{|c|c|}
\hline MERITEV OB ZAČETKU & MERITEV OB KONCU \\
\hline $\begin{array}{l}\text { - še korak dlje do želenega poklica učitelja } \\
\text { - lažje zaposlovanje v šolstsu v prihodnosti, } \\
\text { večja možnost za zaposlitev } \\
\text { - zaposlitev za nedoločen čas } \\
\text { - če hočem učiti, potrebujem boljše pogoje } \\
\text { za zaposlitev } \\
\text { - napredovanje, točke, novosti } \\
\text { - lahko bom poučevala tudi v prihodnje } \\
\text { - dodatna možnost redne zaposlitve na } \\
\text { - pedagoškem področju } \\
\text { la pris svoje izobrazbo praktičnem delu na OŠ } \\
\text { - možnost dela v šolskih knjižnicah oz. z } \\
\text { otroki } \\
\text { - izvajanje seminarjev } \\
\text { - dopolnitev dosedanje izobrazbe } \\
\text { še ne vem }\end{array}$ & $\begin{array}{l}\text { - } \text { samo formalno } \\
\text { - } \text { postala bom učiteljica, saj je PAI pogoj za delo } \\
\text { v šolstvu } \\
\text { - } \text { zaposlitev v naslednjem šolskem letu } \\
\text { - možnost poučevanja } \\
\text { - če bo treba, se bom lahko znašla tudi v razre- } \\
\text { du/skupini, ki naj bi jo poučevala } \\
\text { - potencialno delo ali dopolnilno delo v izobra- } \\
\text { č̌evanju } \\
\text { - pomagalo mi bo postati boljša učiteljica } \\
\text { - daje mi možnost, da bom pri svojem delu vsak } \\
\text { dan boljša, če bom upoštevala navodila preda- } \\
\text { vateljev in se nenehno še naprej izobraževala } \\
\text { na tem področju } \\
\text { - menim, da mi bo usposabljanje nasploh zelo } \\
\text { koristilo } \\
\text { - predavatelj na seminarjih (predvsem računal- } \\
\text { niških) } \\
\text { - pridobitev dodatnega in koristnega znanja } \\
\text { - notranja rast in razvoi iddi }\end{array}$ \\
\hline
\end{tabular}

V tretji, mešani skupini pa je mogoče opaziti predvsem razmišljanje o alternativnih možnostih in vidikih kariernega razvoja s kombiniranjem različnih področij. Udeleženci tako vidijo možne premike kot izboljšanje kakovos dela, pa tudi zadovoljitev osebnih potreb po kakovostnem delu. Med udeleženci je tudi upokojenec, ki meni »da mu bo to usposabljanje omogočilo, da ne bo stagniral in da se bo se naprej izobraževal in čutil koristnega«.

\section{PREGLEDNICA 4: Kakšno spremembo $v$ karieri bo omogočla pridobitev pedagoško-andragoške}

\begin{tabular}{|c|c|}
\hline MERITEV OB ZAČETKU & MERITEV OB KONCU \\
\hline $\begin{array}{l}\text { - upam, da mi bo omogočilo spremembe } \\
\text { - povečale se mi bodo zaposlitvene možno- } \\
\text { - riedna zaposlitev - za nedoločen čas } \\
\text { • odpira se mi možnost prehoda iz nara- } \\
\text { voslovnega v družboslovno področje in } \\
\text { nadaljnji študij } \\
\text { - zaposlitev v zavodu, delo z otroki s poseb- } \\
\text { nimi potrebami } \\
\text { - omogočilo mi bo poučevanje na LU } \\
\text { - morda se bom v prihodnje bolj posvetila } \\
\text { - izobraževanju odraslih } \\
\text { - lahko bom opravljala strokovni izpit za } \\
\text { šolskega bibliotekarja } \\
\text { - odpreti možnosti za alternativne načine } \\
\text { poučevanja } \\
\text { - želela bi predavati na srednji ali visoki } \\
\text { strokovni šoli } \\
\text { - mogoče bom kdaj poučeval } \\
\text { - omogočanje mentorstva z dijaki in } \\
\text { študenti } \\
\text { - ne le možnost učiteljskega poklica, tudi } \\
\text { vodenje delavnic } \\
\text { - to je možna varianta za prihodnost, nikoli } \\
\text { ne veš, kaka priložnost se ti v življenju } \\
\text { ponudi; vsekakor pozitivna izkušnja } \\
\text { - občasno delo kot učitelj, predavatelj } \\
\text { - mogoče bom kdaj želela poučevati } \\
\text { - globlje razumevanje šolskega sistema } \\
\text { - spoznavam čisto nove vsebine glede na } \\
\text { svoj poklic } \\
\text { - razširilo znanja, sposobnosti; pridobivanje } \\
\text { novih izkušenj } \\
\text { - izboljšati svoje delo in odpraviti napake, } \\
\text { ki se pojavljajo pri mojem delu } \\
\text { - pridobitev licence za poučevanje, drugače } \\
\text { na pedagoškem področju ostajam na istem } \\
\text { delovnem mestu, posebnih sprememb ne } \\
\text { bo } \\
\text { - ne vem }\end{array}$ & $\begin{array}{l}\text { - večje možnosti za zaposlitev } \\
\text { - usposabljanje mi daje večje možnosti izbire v } \\
\text { karieri } \\
\text { - mogoče si bom kasneje želela delati v šolstvu } \\
\text { (zdaj sem v vrtcu) - razširjanje manevrskega } \\
\text { prostora } \\
\text { - ker že delam kot učiteljica, vsekakor upam na } \\
\text { ustrezno izobrazbo za opravljanje tega poklica } \\
\text { - mentor } \\
\text { - mogoče se mi bodo odprla vrata za magistrski } \\
\text { - študij iz andragogike } \\
\text { - dodana vrednost ne glede na poklic, ki ga } \\
\text { opravljam (ki ga bom opravljala) } \\
\text { - novo področje, odprtje novih možnosti in } \\
\text { priložnosti } \\
\text { - pogodbeno delal v eni izmed zdravstvenih } \\
\text { šol, vendar moje osnovno področje delovanja } \\
\text { ostaja isto, »psihiatrija« } \\
\text { - lahko bom opravljala strokovni izpit za šolske- } \\
\text { ga knjižnčcarja } \\
\text { - razumevanje dela z mladimi } \\
\text { - splošno pedagoško znanje } \\
\text { - olajšalo mi bo delo v službi, dalo motivacijo } \\
\text { za delo s študenti } \\
\text { - določeno znanje bom izkoristil za boljše delo } \\
\text { v razredu, za boljši izkoristek } \\
\text { - delo z otroki s posebnimi potrebami } \\
\text { - omogočilo mi bo kvalitetnejše izvajanje in } \\
\text { načrtovanje programov neformalnega izobra- } \\
\text { ževanja oz. izbirnih predmetov formalnega } \\
\text { - menim, da mi bo prineslo veliko koristi na } \\
\text { osebnem področju - kar bom prenesla tudi na } \\
\text { osebno področje } \\
\text { - zadovoljitev lastnih potreb } \\
\text { - ker sem v pokoju, mi bo to usposabljanje } \\
\text { omogočilo, da ne bom stagniral in da se bom } \\
\text { še naprej izobraževal in čutil koristnega } \\
\text { - za zdaj nobene spremembe } \\
\text { - še ne vem }\end{array}$ \\
\hline
\end{tabular}


Kot vidimo iz predstavljenih odgovorov, v učiteljske vrste vstopajo posamezniki z zelo različnimi pričakovanji, predhodnimi izkustvi in kariernimi ambicijami. Da pozna posamezna načela načrtovanja in vodenja kariere na področju izobraževanja, pa ni pomembno samo za učitelja. Ta znanja so nujno potrebna tudi ravnateljem in direktorjem izobraževalnih ustanov, ki pomembno sodoločajo karierno pot učiteljev. Preučevanje razvoja karier pri nas (Javrh, 2006; Javrh, 2008) kaže, da ima učiteljeva kariera nekatere specifike, ki opazno zaznamujejo poklicno pot $\mathrm{v}$ tej panogi. Kot sem opozorila že uvodoma,je za načrtovanje tako osebne kot institucionalne kariere treba upoštevati tako univerzalne kot specifične zakonitosti.

Udeležence smo spraševali tudi, ali pričakujejo, da se bodo po pridobitvi pedagoško-andragoške izobrazbe zaposlili na področju izobraževanja.

Odgovori kažejo, da 36,6 odstotka vprašanih že dela v izobraževanju, torej potrebujejo pridobitev formalnih pogojev, kar jim omogoča PAI. 31 odstotkov jih pričakuje zaposlitev v izobraževanju. Sem lahko štejemo del odgovorov pod izbiro drugo, saj ti udeleženci večinoma že opravljajo pedagoško delo ali so ga že opravljali. Kar 14,4 odstotka pa jih ne ve, kar najverjetneje pomeni, da še niso odločeni.

Primerjava rezultatov začetne in končne meritve pokaže negativno težnjo v pričakovanjih - pričakovanja udeležencev glede zaposlitve so se znižala. Kvalitativna analiza njihovih odgovorov, kaj še pričakujejo, pa pokaže, da si v resnici še želijo delati kot učitelji, čeprav ob koncu programa razmišljajo veliko bolj fleksibilno in vidijo tudi različne alternativn fleksibilno in možnosti.

Udeleženci v skupini z zelo malo pedagoškimi zkušnjami so ob vstopu v program razmišljali
PREGLEDNICA 5: Pričakovania udeležencev programa PAI glede zaposlitve v izobraževan

\section{PRIČAKOVANJE} ZAPOSLITVE $V$ DELEŽ IZOBRAŽEVANJU (v \%)

\section{Ne, ker že delam na področju izobraževanja}

$\mathrm{Ne}$, ne pričakujem in ne delam v izobraževanju

Da, pričakujem, čeprav še ne delam v izobraževanju

\section{Ne vem}

Drugo Ni podatka

Skupaj

36,6

tudi o tem, da bo s tem »dana še ena možnost zaposlitve, ki je ne izključujejo«, »pričakujejo, da se bodo ponovno zaposlili na področju izobraževanja«, »upajo na delo v izobraževanju « ali da se bodo usmerili v »premoženjsko svetovanje - izobraževanje sodelavcev«. Ob koncu usposabljanja so previdnejši: »morda po konč nni glasbeni karieri v moji stroki«, po konc a ga okviru kiparskega delovanja - med drugim udi vodenje likovnih delavnic, morda tudi delo v vrtcih in šolah« ali menijo: »rada bi poučevala, čeprav tudi zdaj delam $\mathrm{v}$ šolstvu, samo ne kot učiteljica《.

Tisti, ki imajo že več izkušenj s poučevanjem, so tako ob vstopu kot ob koncu usposabjem, predso ob vs zopabljanja predvsen usmerjeni v razmišljanje o zadostitvi formalnim pogojem: »trenutno nadomeščam porodniško in upam, da se bom lahko prihodnje leto zaposlila $\mathrm{v}$ šolstvu«, »da pričakujem, ampak bi rada poučevala še kakšen

Udeleženci v mešani skupini so ob začetku usposabljanja navedli: »že zdaj sem zaposlena v podjetju, ki se ukvarja z izobraževanjem«, »ker sem že nekaj let na javnih delih v izobraževanju«, »konec leta se upokojim«, »v prihodnosti bi želela delati tudi kot učitelj«, »to je možna varianta za prihodnost, nikoli ne veš, kaka priložnost se ti y življenju ponudi«; »vsekakor pozitivna izkušnja, odprta možnost«, »delam v vrtcu, verjetno se bom kdaj kasneje želel preizkusiti tudi v delu na šolik, Ob izteku pa so o možnosti zaposlitve v izobrǔ̌evanju razmišljali takole: pričakujem, Čeprav že delam na področju izobraževanja in želim $\mathrm{v}$ tem poklicu tudi ostati«, »poleg strokovneg poklica bi se želela zaposliti v ustanovah za neformalno izobraževanje«, »med programom PAI sem dobila službo učitelja v OŠ «, »ne še takoj, ampak čez nekaj let«, »da, ker sem trenutno na javnih delih v izobraževanju«, »bi ostala zaposlena na svojem področju z večjim poudarkom na delu s študenti in svojci«, »sem že zaposlena na področju izobraževanja, vendar ne poučujem, pričakujem pa, da bom«, »priložnostno poučevanje «.

drug predmet, kjer potrebujem to izobrazbo«, »formalizacijo mojega vseživljenjskega dela«.

Kakšno naj bo torej ustrezno izobraževanje tako bodočih kot že aktivnih učiteljev? Tudi o tem smo spraševali bodoče učitelje, ki prihajajo iz drugih panog. Udeleženci PAI so kot pogoj za odlično usposabljanje najpogosteje navajali: veliko diskusij o konkretnih primerih in praktični napotki. Zelo poudarjena je praksa, kot potrebno so jo omenjali tako tisti, ki ne de. Za oboje je opazovanje prakse izkušenega učitelja, osebno izkustvo, kasneje pa evalvacija lastnega dela tisto, kar vidijo kot ustrezno al celo odlično usposabljanje. Poudarjajo, da bi se pravo razmerje med teorijo in prakso moralo nagniti bolj na stran praktičnih izkušenj, ki jih nato teoretsko obdelajo in osmislijo. Zagotoviti bi bilo treba dovolj časa za praktično delo v okviru pos dovj ca za prakično sabljanja. Odlično usposabljanje po njihovem $\mid$ novo dinamiko in moderno raznovrstno znanje.

Pogosto udeleženci povezujejo odličnost usposabljanja tudi z angažiranimi, kompetentnimi, ustrezno usposobljeni predavatelji, ki so sposobni razumljivega posredovanja znanja. Precej so kritični do togih in preveč akademsko naravnanih predavateljev. Kot nezaželene načine dela pa navajajo seminarske naloge, preveč teorije, preveč frontalnega dela, preverjanje znanja na podlagi na pamet naučenega, premalo (osebnih) srečanj s predavatelji, premalo natančna navodila o pogojih za pristop $\mathrm{k}$ izpitu. Udeleženci $\mathrm{k}$ odličnosti prištevajo tudi povezanost vsebin z osebnimi interesi in delom. Nekateri udeleženci menijo, da bi lahko bolj izkoristili e-izobraževanje $z$ dodatnimi konzultacijami in podporo. deležencev, njihovo osvetlitev, evalvacijo. V ospredje so postavljali obliko timskega dela li delo v manjših skupinah, kjer bi prevladovalo sproščeno ozračje, $\mathrm{z}$ intenzivno izmenjaKot lahko vidimo iz analize stališč udeležencev PAI, imajo ti ob vstopu v izobraževanje kovanja in večinoma ustrezno motivacijo za poučevanje in delo z učečimi. Njihov glavn motiv za vstop v profesionalno delo učitelja ni ekonomski. V ospredju je motiv osebne raTo pas sovostno profesionalno rastjo. pa so v resnici ugodna izhodišča za pozitakovostni razvoj karier bodočih učiteev. Ti učitelji so za izobraževalni sistem še kako pomembni, če imamo v mislih, da imajo ušnje $\mathrm{v}$ drugih poklicih in lahko zato $\mathrm{v}$ sisnovo dinamiko in moderno raznovrstno znanje. (pa še tudi ob njegovem koncu) velika priča- 


\section{SKLEP}

Izobraževanje ima nenadomestljivo vlogo pr ozaveščanju o potrebnosti načrtnega pristop $\mathrm{k}$ procesom razvoja kariere, motiviranju za nove cilje v kariernem ciklusu, poglabljanju uvidov o delovnem kontekstu na strokovnem področju, obnavljanju in širitvi ter sistematiziranju novih, pri delu potrebnih strokovnih spoznanj, pomoči pri sledenju razvoja strok kot zagotavljanje možnosti za pridobitev novih spretnosti. Pa ne le to: ozaveščati in usposabljati mora celostno, v smeri humanističnih izhodišč in vzdržnega razvoja.

zaostrenih gospodarskih razmerah so načrtovanje in vodenje kariere ter $\mathrm{z}$ njima povezano izobraževanje na prepihu. Lahko pričakujemo, da se bo v prihodnosti tudi pri nas na vse bolj odprtem trgu »izobraževalnih storitev pojavljalo še več »izobraževalcev« za hiter, bliskovit uspeh v karieri, to je ljudi, ki bodo poskušali na nestrokoven način voditi druge, še posebno tiste, ki se znajdejo na katerem od težjih »prehodov« ali »križiščc v s svojem življenjskem ciklusu. Ena od nalog andragoške teorije bi morala biti ozaveščanje o pomen in nujnosti zadostne strokovne usposobljenosti izobraževalca, ki bo odraslega vodil po zamotani poti izobraževanja odraslih in mu pomagal razvijati kariero, in to ne glede na dizobraževaec odraslih «. Karierni svetovalec bi moral dealni situaciji doseči zelo zahtevne cilje, saj naj bi »spoznal izkušnje, interese, prepričanja, vrednote, delovne navade in osebne kvalitete svetovanca ter vsakega izmed njih usposobil do te mere, da si zmore ustvarjati zadovoljno življenje s stalnim spreminjanjem delovnega okolja《 (Krumboltz 1997: 65). Njegova temeljna naloga v vlogi izobraževalca odraslih pa bo še naprej, da pospeši učenje.

Odrasli, ki ne bodo znali oblikovati strategije vojega kariernega razvoja, bodo delavci brez prihodnosti. Krumboltz glede pomoči, ki jo pri tem odrasli lahko dobi od usposobljenega strokovnjaka, poudarja: »Posamezniki, ki verjamejo, da jim izpopolnjevanje ni potrebno, potrebujejo tako soočenje $\mathrm{z}$ novo stvarnostjo, ki jih bo motiviralo in navdihnilo $h$ konstruktivni spremembi.« (1997: 61.) Vse zgoraj navedeno enako velja tudi $z$. tudi za učiteljevo kariero, bodisi da dela na področju izobraževanja otrok in mladine bodisi odraslih.

Učitelji ob izteku začetnega izobraževanja oziroma ob vstopu $v$ poklic še ne morejo imeti vseh potrebnih kompetenc. Oblike izobraževanj, ki so učiteljem sistemsko na voljo, segajo od usposabljanja, pripravništva, specializacije, preusposabljanja (prim. Jelenc, 1991) do priučevanja, uvajanja, prekvalifikacije in celo poklicne rehabilitacije (prim. Jereb, 1998). Postavlja pa se vprašanje, ali so ustrezne in ali res podpirajo zaželeni razvoj kariere.

Kakovostno usposabljanje je zelo pomembno pri krepitvi profesionalnega razvoja učitelja. Učitelj mora sebe videti kot kompetentnega in odgovornega profesionalca ne glede na obdobje poklicne poti in ne glede na konkretno vlogo, ki jo ima. Premajhna pozornost, namenjena krepitvi učiteljeve samopodobe in utrjevanju poklicne socializacije, povzroča odpor do udeleževanja v obveznih oblikah stalnega popolnievanja. Učitelji so zelo kritični do premalo skrbno pripravljenih usposabljanj. V različnih obdobjih poklicne poti imajo namreč različne potrebe glede utrjevanja lastnega ugleda in samopodobe. Nepoznavanje kariernega razvoja in specifik poklicne poti onemogoča načrtovanje različnih izvedb programov, ki bi bili prilagojeni določeni staskupini učiteljev (mlajši, zreli učitelji, razredniki, seniorji ...) oziroma učiteljem glede na njihov karierni razvoj, ne glede na to, ali trenutno delajo kot učitelji mladine, otrok ali kot izobraževalci odraslih.
Eden od bistvenih ciljev novega programa za usposabljanje učiteljev na področju kariernega razvoja, ki ga pravkar razvija Andragošk center Slovenije, je prav ta: učitelje naj bi skozi tri med seboj prepletene module usposobi do te mere, da bodo lahko sami načrtovali in razvijali dobršen del svojega profesionalneg razvoja v vlogi učiteljev. Danes posameznik sam postaja odgovoren za kakovost razvoja lastne kariere ne glede na poklic. Zato mora znati jasno artikulirati svoje potrebe. Poznat mora pomembnost prepletenosti in vpetost kariernega cikla v druge procese, ki tečejo v njegovem življenju kot celoti. Pomembno je, da tako postaja aktiven sooblikovalec organizacije, v kateri dela.

1 V nadaljevanju bom izraz učitelj uporabljala v najsisiršem

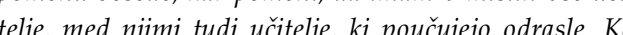
se podatki nanašajo izkljiǔčno na področje izobră̌evañ odraslih uporabljam izraz izobraževalci odraslih.

V okviru mednarodne študije INCLUD-ED sodeluje 1 evropskih univerz in dva inštituta: prikazani podatki nanašajo na projekt $3, v$ katerem so sodelovale Španija, Slovenija, Italija, Avstrija, Belgija, Finska, Romunija in komisija EU v Bruslju. glej v: Javrh, P., Kalin, J., Muršak, J. (2010). Progran usposabjanja za ucitelje kot kjucni dejavnik modernzacije sóle in medgeneracijskega sodelovanja. Ciljni raziskovalni projekt 2008-2010. Zahjucno poročilo. Ljubljana: ZIFF, Univerza v Ljublian

4 Podatki so bili pridobljeni v okviru projekta Program usposabljanja za ucitelje kot ključni dejavnik modern-

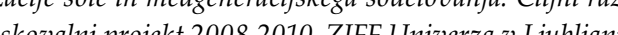
istoring

\section{LITERATURA}

Eraut, M. (1993). »Teacher accauntability: Why is it central in the teacher professional development $\ll$. V Kremer-Hayon, L., Vonk, H. C., Fessler, R. (ur.). Teacher professional development: A multiple perspektive approach. Amsterdam/Lisse: Swet \& Zeitlinger B. V.
Ivančič A., Mirčeva J., Vrečer N. - SIAE (Slovenian Institute for Adult Education) (2008). Impact of education on health. Literature Review Report
(youth, women people with disabilities). Interim Report. WorkPackage 10. Includ-ed. Strategies for Inclusion and Social Cohesion in Europe from Education. FP6 European Commission. (20062011)

Jamšek, D., Javrh, P. (2009). »Osnovna šola - izobraževalno in kulturno srce trajnostnega ravnanja za najbolj ranjjive? «Andragoška spoznanja. Letnik 15, št. 2: 36-44.

avrh, P. (2006). Razvoj kariere učiteljev in njihovo izobraževanje. Doktorska disertacija. Ljubljana: Univerza v Ljubljani, Filozofska fakulteta.

Javrh, P. (2008). Spremljanje in načrtovanje razvoja kariere učiteljev po

Javrh, P. (2009). EU recommendations and directives on the EKS in health. Ljubljana: Slovenian Institute for Adult Education.

Jelenc Krǎsovec, S. (2009). »Starejši judje med dem in prostim časom $\ll . \mathrm{V}$ Ličen, N. (ur.). Medučenja: strokovni posvet, Novo mesto, 22, oktober 2009: [zbornik vabljenih predavanj]. Ljubljana: Andragoško društvo Slovenije: 43-60.

Jelenc, Z. (1991). Sistemsko urejanje izobraževanja odraslih v Sloveniji. Ljubljana: Pedagoški inštitut. Jereb, J. (1998). Izobraževanje in usposabljanje kadrov. Management kadrovskih virov. Ljubljana: Fakulteta za družbene vede.

Klette, K. (2000). »Working-time blues, How Norrwegian teachers experience restructuring in $\mathrm{E}$. Moller, J. (ur.). The life and work of teachers international perspectives in changing times. London, New York: Falmer press.

Krumboltz, D. J. (1997). »Aplikacija teorije učenja Pris suetovanju za karierou. VNiklanovic, S. (yr). Izida: 57-88.

Marentič Požarnik B., Kalin J., Šteh, B., Valenčič Zuljan, M. (2005). Učitelji v prenovi - njihova Znanstveni inštitut Filozofske fakultete.

Možina T. in drugi (2009). Evalvacija izobraževalne ponudbe formalnih in neformalnih programov za
brezposelne. Andragoški center Slovenije, inter brezposelne. Andragoški center Slovenije, interno
gradivo. 
Prikaz dosežkov in razvojnih izzivov (2008). Prikaz dosežkov in ra nosti Andragoškega centra Slovenije. IZhodišča oblikovanje nove zasnove andragoškega spopolnjevanja. Ljubljana: Andragoški center Slovenije. Razdevšek-Pučko, C. Rugelj, J. (2006). NKompetence v izobrǎ̌e cinju ǔ̌iteljev. Vzoja in izobră̌ vanje. Št. 1, let. 37: 46-50.

SSKJ (1993). Slovar slovenskega knjǐ̌nega jezika. Ljubljana: DZS. 3. knjiga: 598.

Statistični urad RS (2007). Svetovni dan učiteljev. 3. Otober 200\%. Posebna objava. http://www.stat.si novica_prikazi.aspx?id=1183 (dostopano: 15.12 2009)

Valenčič Zuljan, M., Vogrinc, J., Bizjak, C., Krištof. Z., Kalin, J. (2007). Izzini mentorstva: učbenik. Ljubljana: Pedagoška fakulteta.

Vrečer, N., Javrh, P. (2009). »INCLUDED - izo- braževanje kot dejavnik družbene vključenosti: učenja pri reševanju problematike rev̌ščine. Ljubljana: Center RS za mobilnost in evropske programe izobraževanja in usposabljanja (CME US): Zveza ljudskih univerz Slovenije (ZLUS). Vrečer, N. (2010): „Vocational education and training, employment - related mobility and migration «. V Dve domovini / Two Homelands. Št. 32. Wragg, E. C. et al. (1996). Teacher appraisal observed. London, New York: Routledge.

Zelena knjiga o izobraževanju učiteljev v Evropi

(2001). Tematsko omrě̌je o izobraževanju učiteljev v Evropi-TNTEE. Ljubljana: Ministrstvo za slstvo, znanost in šport.

Žalec, N., Đordevič, N. (2009). Razvoj novih pristopov pri spopolnjevanju andragoških delavcev. . enter Slovenije, interno gradivo.

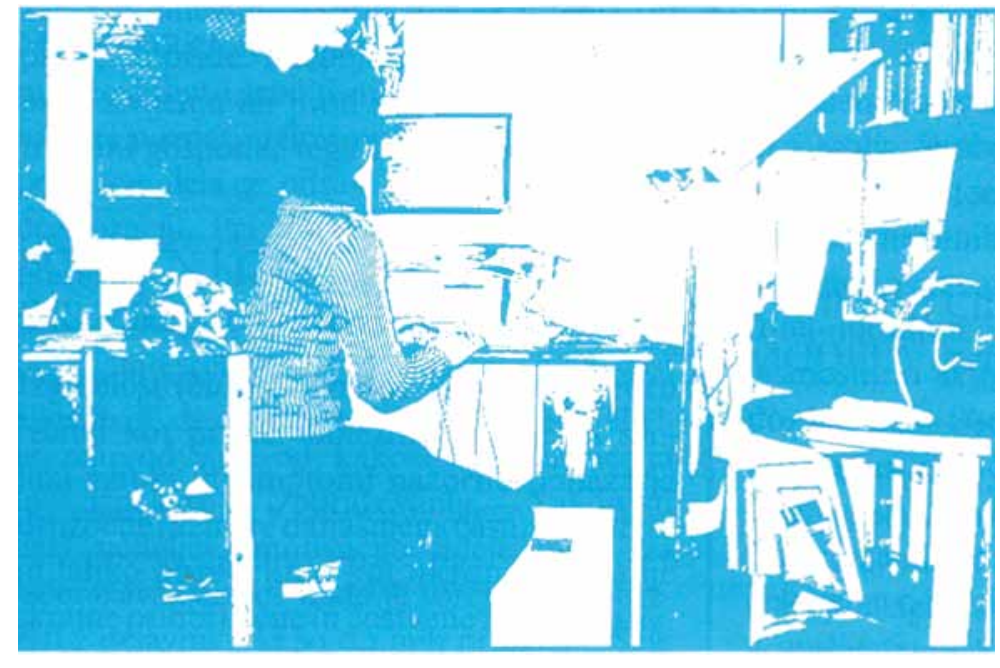

ZA BOLJŠO PRAKSO

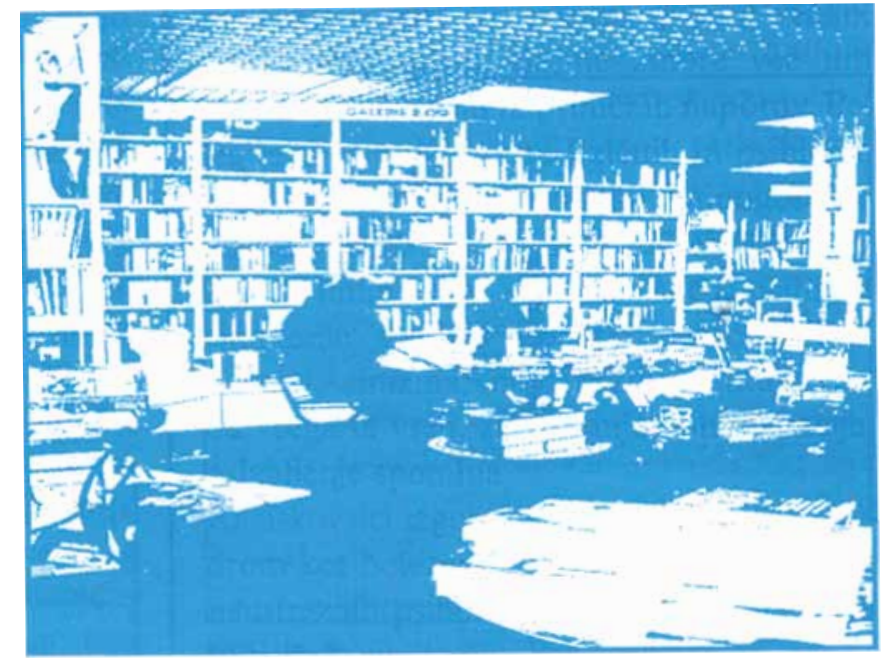

